\title{
Dieste, González Zuleta and Sánchez del Río: Three approaches to reinforced-brick shell structures
}

\author{
D. López López, T. Van Mele \& P. Block \\ Block Research Group, Institute of Technology in Architecture, ETH Zurich, Switzerland
}

\begin{abstract}
Reinforced-brick shell structures are mainly known through the extraordinary work of the Uruguayan engineer Eladio Dieste. However, other remarkable examples of shells in reinforced masonry were being built during Dieste's development of the technique or even before. The works by Guillermo González Zuleta in Colombia and Ildefonso Sánchez del Río in Spain deserve a closer look. Analysis of the three engineers' backgrounds, writings and work reveals different original conceptions of the technique. The conceptual approach to the reinforced brick material and the way they approached challenges and obstacles are very different in the three cases, yet they finally achieved similar structural solutions.

This document presents a review of historical reinforced masonry architectural examples by these three master builders. The paper analyses their roles in the development of this technique and presents some of their most influential or striking architectural pieces.
\end{abstract}

\section{INTRODUCTION}

By far, the most well-known individual in the field of reinforced-brick shell architecture is the Uruguayan engineer Eladio Dieste (1917-2000). Dieste's contribution to the Berlingieri House (1946-47) by Antoni Bonet led to what is acknowledged by many historians to be the first reinforced-brick vaults (Dieste 1947, Marín \& Trallero 2005, García \& Beltrán 2014). Although not the first to use this material combination (Ochsendorf 2004, Cabeza et al. 2009, Churtichaga 2010), his system was indeed a new way to use brick, steel reinforcement and mortar, and marked the beginning of Dieste's extraordinary and inspiring work with the material that he later called "cerámica armada" (reinforced ceramic) (Dieste 1987).

However, after this invention, he did not use his new technique again until 1955 . Precisely between the years 1946 and 1956, the Colombian and Spanish engineers Guillermo González Zuleta (1916-1995) and Ildefonso Sánchez del Río Pisón (1898-1980) built remarkable architectural pieces using reinforced brick. In the case of the latter, his work in that period also preceded what would be his most relevant contribution related to reinforcedbrick construction: the prefabricated elements called "undulating voussoirs" ("dovelas-onda") with which he built shells with spans up to $100 \mathrm{~m}$ (Sánchez del Río 1977).

\section{ELADIO DIESTE: THE BRICK AS THE ESSENTIAL ELEMENT}

\subsection{Approach to reinforced-brick shell structures}

In 1945, the Spanish architect Antoni Bonet moved from Buenos Aires to Punta Ballena, Uruguay, to design and build an urbanization project in the area (Álvarez \& Roig 1996). He contacted Eladio Dieste, who had graduated two years before as a structural engineer, and proposed that he build concrete barrel vaults at the Berlinghieri House, similar to the ones Bonet had already successfully built for the Houses in Martínez, Argentina (1941-1942). After some discussions and as proposed by Dieste, the vaults were finally built with reinforced brick in 1947 (Petrina 1988, Tomlow 2001, Ochsendorf 2004). He claimed that his idea came from merging his desire to make a masonry membrane and his previous experience with mobile formworks for thin, concrete shells (Petrina 1988, Marin \& Trallero 2005).

His intentions to move away from concrete structures were clear. He knew he was building something different from thin, concrete shells, and he referred to his construction technique as reinforced ceramic, in which the brick was the essential element and was always left exposed. The use of brick was therefore not arbitrary, but meditated and justified in Dieste's writings (Dieste 1987). As it will be shown later, this conceptual approach to the reinforced-brick material 


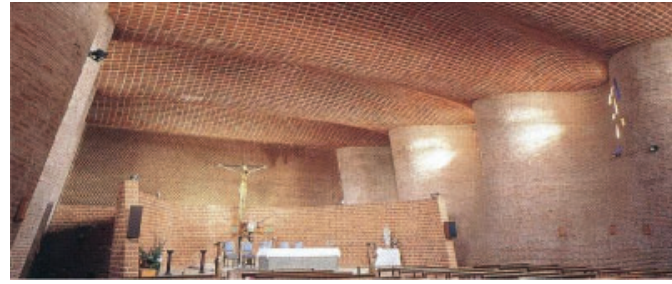

Figure 1. Church of Christ the Worker in Atlántida, Montevideo, Uruguay. Eladio Dieste (1958-60) (Daguerre 2003).

was very different from the way the other two main protagonists of this paper approached their challenges and obstacles, though the results were similar.

\subsection{First works using reinforced-brick shells}

Eladio Dieste built two self-carrying, thin, concrete vaults in 1947 and 1948, and, as mentioned above, he did not use reinforced-brick shells again until 1955, when he built the warehouses for ANCAP ( $8 \mathrm{~m}$-span, cylindrical, barrel vaults) and Frugoni ( $22 \mathrm{~m}$-span, doubly-curved vaults with skylights) in Montevideo, Uruguay. He built some other, barely known shells, including the silos for Banco República in Cardona and Tarariras, Uruguay, in 1955 (Grompone, unpubl., Anderson 2004), before the construction of his famous church of Christ the Worker in Atlántida, near Montevideo (1958-60) (Figure 1). After building this church, he published a second paper featuring his reinforcedbrick technique (the first was in 1947) in the Spanish journal "Informes de la Construcción" in 1961. This was followed by many other publications, and his architecture began to gain recognition.

\subsection{Influences}

Dieste's buildings have served as examples for many architects and/or engineers, and numerous architectural examples featuring reinforced brick are inspired by his work. On the other hand, his structures also have some precedents, such as the work of Guillermo González Zuleta in Colombia and Ildefonso Sánchez del Río in Spain.

Regarding the architectural pieces built by the Colombian engineer years before Dieste built more sophisticated but very similar constructions, it seems probable that the Uruguayan knew about G. Zuleta's pioneering work. However, in Dieste's interview in 1978 (Arana \& Garabelli 1980), he refers to Colombia and implies that the reinforced-brick technique was not at all commonly used at that time. It can be inferred that Dieste knew about Colombian architecture and construction techniques. However, he did not mention the work of G. Zuleta in the late 40 s and the 50 s. On the other hand, direct references to Sánchez del Río's work can be found in Dieste's writings. His paper Estructuras Cerámicas (Dieste \& Montañez 1963) refers to some buildings by Sánchez del Río (Chiorino 2003).
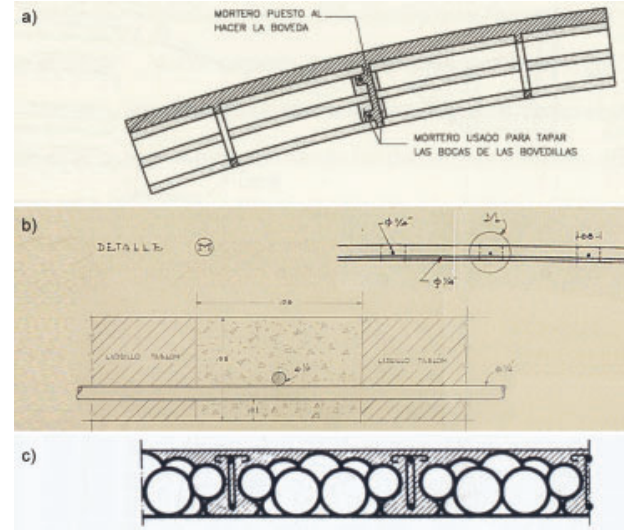

Figure 2. Construction details by a) Dieste (Consejería de Obras Públicas 1996), b) G. Zuleta (Galindo 2015, pers. comm.), and c) Sánchez del Río (Sánchez del Río 1957b).

\section{GUILLERMO GONZÁLEZ ZULETA: LIGHTER, THIN CONCRETE SHELLS}

\subsection{Approach to reinforced-brick shell structures}

Colombia is known for its tradition and resources for brick production (Petrina 1988). This fact can be perceived when visiting the country and has led to quality brick architecture by Colombian architects such as Rogelio Salmona (1929-2007), who worked with Le Corbusier on the Jaoul Houses, which feature tile vaults (Rodríguez 2008). He also used brick as the most predominant construction element in walls, floors, various kinds of vaults, pavement, stairs, etc. (Adell 2005). Less known, at least beyond Colombian borders, are the contributions of some architects and engineers, such as G. Zuleta and Jorge Gaitán Cortés, to reinforced-brick, shell architecture.

This Colombian episode in the history of reinforced brick evolves from thin, concrete, shell architecture (following the trends of that time and inspired by masters like Eduardo Torroja and Pier Luigi Nervi) and the purpose of achieving a lighter structure by introducing bricks. Although using different material proportions, the resulting structural concept is similar to the one used by Dieste, with steel reinforcement in between the ceramic elements working in compression. Nevertheless, whereas Dieste introduced the reinforcement in the mortar joints, sometimes using special ceramic pieces (Figure 2a), González Zuleta used concrete and left a bigger space between bricks, having ribs instead of joints (Figure $2 b$ ).

These differences respond to the contrast in the conception of each of these approaches. The vast majority of the Colombian literature consulted here refers to the reinforced-brick architectural pieces in Colombia as thin, concrete shells, explaining the contribution of the ceramic elements (if mentioned at all) on a secondary level. This makes it very difficult to identify some of the reinforced-brick shells (which are normally rendered), even if they had an impact 
at a local or international level. Information should be searched in the original construction or structural plans and through inspection of buildings. These facts, together with the Colombians' humble nature (which did not help to recognize innovative constructions with a modest and traditional material), might help to explain why the exceptional work on reinforced-brick shells in Colombia has not yet received international recognition.

\subsection{First works using reinforced-brick shells}

Guillermo González Zuleta was the main contributor to Colombian reinforced-brick shell architecture. He was part of the team working on the first, significant thin-shell construction in Colombia: the Girardot Market (1946-51) by the architect Leopoldo Rother, which featured 198 thin shells, each $7 \mathrm{~m}$ long, $2.5 \mathrm{~m}$ wide and $5 \mathrm{~cm}$ thick. Leopoldo Rother referred to the shells as "concrete, thin shells" ("membranas de concreto") (Rother 1967), however, the architect Jorge Gaitán Cortés (also working on the project) mentioned the use of bricks to achieve a lighter structure (Galindo 2015, pers. comm., Vargas \& Galindo 2015, Rother 1984). A recent inspection by Dr. Jorge Galindo (Universidad Nacional de Colombia), confirmed the use of ceramic in the building's structure (pers. comm., Galindo 2015). Regarding the structural assessment of the building, a full-scale prototype of a (probably reinforced-brick) vault was built and tested, since in 1946 - one year before the construction of Dieste's Berlinghieri House - there was no previous experience on the calculation of thin shells in Colombia (Rother 1967).

In 1947, G. Zuleta was in charge of the structural design of the internationally recognized Baseball Stadium "11 de Noviembre" in Cartagena (Vargas \& Galindo 2015). To achieve a lighter structure, the formwork of the shells included removable wooden molds, whose shape can be seen in the result. Regarding the use of ceramics, although it is still standing, lacking an inspection of the building, the use of ceramic elements is still not clear according to the literature. Construction plans from September 1947 show the mentioned wooden molds in some drawings and a reinforcedbrick structure in others (Archivo General de la Nación 1947). Whether or not G. Zuleta finally used bricks in the Girardot market and/or in the Baseball Stadium, his construction plans already show his idea of using ceramics in the thin, concrete shell in September 1947.

Dieste's article: "Bóveda nervada de ladrillos 'de espejo" ("Ribbed vault made of "mirror bricks"), in which he explains his invention of reinforced-brick vaults in the Berlinghieri House and mentions a larger vault that he had tested, was also published in September 1947 in the local journal "Revista de Ingeniería". Considering the time frame, location and their construction plans and writings, it seems that Dieste and G. Zuleta developed their systems in parallel, with different conceptions, but resulting in similar techniques.

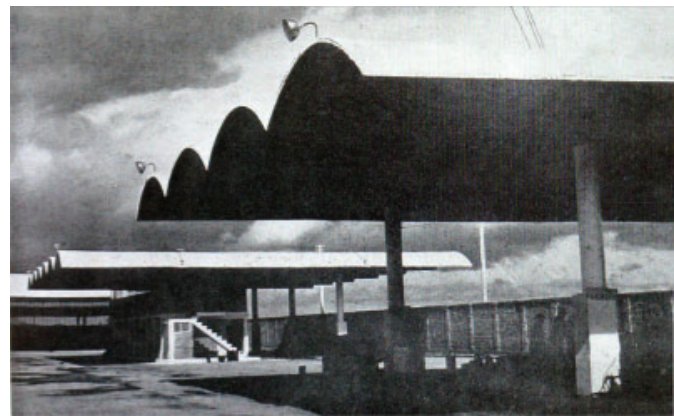

Figure 3. Bus terminal in Bogotá, Colombia. Guillermo González Zuleta, 1950 (7arquitecturas 2001).

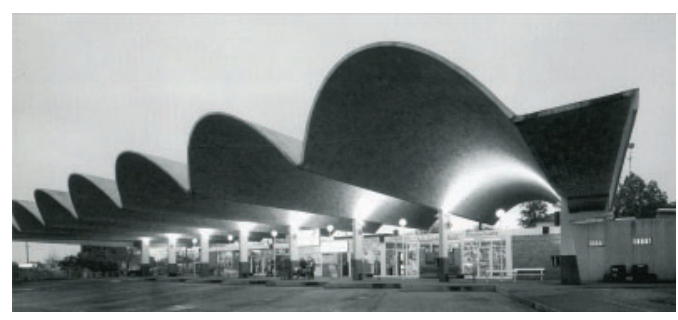

Figure 4. Salto municipal bus terminal, Uruguay. Eladio Dieste, 1973-74 (Anderson 2004).

In any case, G. Zuleta's work in the next years anticipated what was to be seen (and refined) in Dieste's architecture some years later.

\subsection{G. Zuleta's work, a predecent to Dieste's architecture}

G. Zuleta used reinforced brick to build a bus terminal in Bogotá, Colombia, in 1950 (Figure 3). The structure consisted of double-cantilevered, single-curved, self-carrying vaults supported by one or two lines of columns. The membrane structures were built using a mobile formwork and were $5 \mathrm{~cm}$ thick, with a reinforcement of only $5 \mathrm{~kg} / \mathrm{m}^{2}$ (Vargas \& Galindo 2015). Sometime later, G. Zuleta would name these selfcarrying vaults "laminar beams", in reference to the minimum thickness that they could achieve (7arquitecturas 2001). This exceptional architectural piece (demolished in the 80s) has clear similarities with many of the buildings with self-carrying, reinforcedbrick vaults that Dieste would build later, especially the municipal bus terminal (1973-74) and the Turlit bus terminal (1980), both in Salto, Uruguay (Figure 4) (Anderson 2004; Consejería de Obras Públicas y Transportes 1996). Dieste explored the use of selfcarrying, reinforced-brick vaults for the first time in his house in 1961, to "first see how the structure behaved, and establish the theory afterwards" (Eladio Dieste, in Petrina 1988). That was 11 years after G. Zuleta's bus terminal in Bogotá.

After this experience, G. Zuleta entered a period of innovation in the field of reinforced brick during 


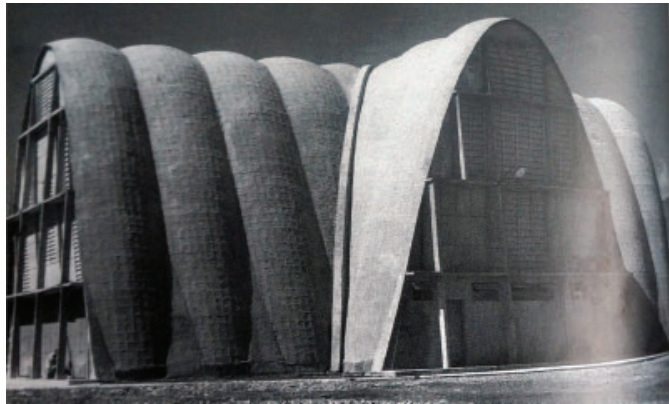

Figure 5. Chapel of Universidad Pontificia Bolivariana in Medellín. Guillermo González Zuleta, 1952 (Vélez et al. 2010).

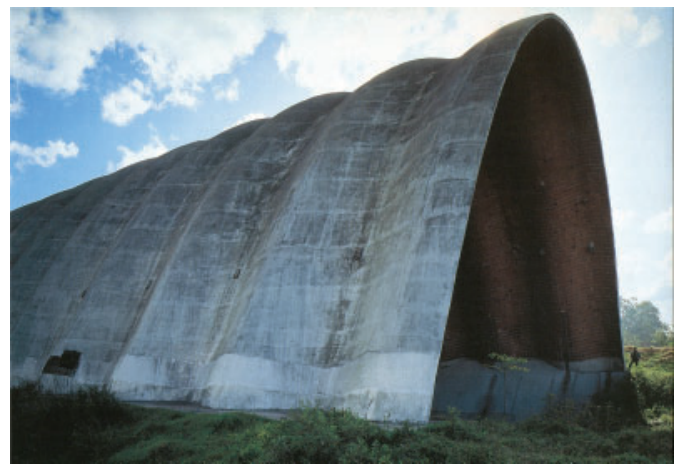

Figure 6. Cadyl horizontal silo in Young, Uruguay. Eladio Dieste, 1976-78 (Anderson 2004).

the 1950s (Vargas 2009). By 1956 G. Zuleta would build three religious buildings using this technique: 1) the church of Nuestra Señora de Fátima in Medellín (1950-54), a project by the architect Antonio Mesa, in which G. Zuleta used the so called "hat brick" (section 3.4.); 2) the chapel of Universidad Pontificia Bolivariana in Medellín (1952) (Figure 5), whose repeated pattern of contiguous vaults (not continuous in shape) recalls the preceding Orly hangars (1923), but also anticipates Dieste's future horizontal silos (Figure 6); and 3) the chapel of Gimnasio Moderno in Bogotá (1954-56), with its $70 \mathrm{~mm}$-thick, $12 \mathrm{~m}$-high, reinforced-brick shells (Cortés 2014).

The Rayo Supermarket (1955), the Volkswagen building (1955) (Figure 7) and the Techo racecourse (1956), all in Bogotá, also by G. Zuleta as structural engineer, utilized reinforced brick. The Rayo Supermarket, by the architects Francisco Pizano and Roberto Rodríguez, has a central reinforced brick shell with a span of $22.5 \mathrm{~m}$ and a thickness of $5 \mathrm{~cm}$ (Vargas 2015). The Volkswagen building by the architect Bruno Violi features an undulating and continuous vaulted roof with skylights made of glass blocks to light the interior space (Vargas \& Galindo 2015; PROA 1955a). The Techo racecourse by the architect Álvaro

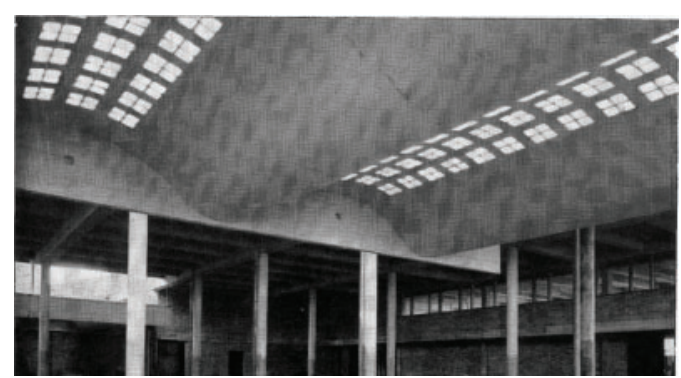

Figure 7. Volkswagen building in Bogotá, Colombia. Guillermo González Zuleta, 1955 (Proa 1955a).

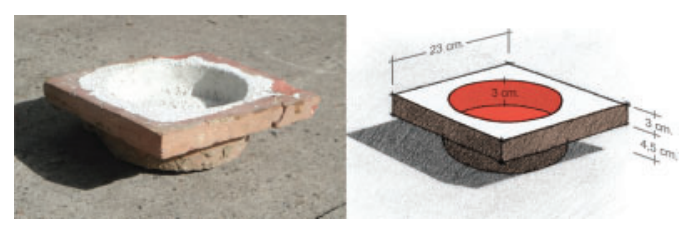

Figure 8. Hat brick" by Jorge Gaitán Cortés (Gutiérrez 2011).

Hermida (PROA 1952, 1955b, 1958) presents $23 \mathrm{~m}$ cantilevering beams supporting perpendicular, $5 \mathrm{~cm}$ thick, single-curved, self-carrying, reinforced-brick vaults.

The undulations of the Volkswagen building's roof (Figure 7) recall those of the first renowned building by Dieste: the church of Christ the Worker in Atlántida (1958-60) (Figure 1). Although the latter has double curvature and achieves a higher level of structural refinement and sophistication, they have a similar shape and central cross-section. Furthermore, the skylights of the building in Bogotá are also a precedent for those used by Dieste in the Autopalace in Montevideo, Uruguay, (1964) or the Rio Metro Maintenance Hangar in Rio de Janeiro, Brazil, (1971-79).

\subsection{The "hat brick"}

Some of G. Zuleta's works during the 1950s were completed together with the architect Jorge Gaitán Cortés, with whom he had already worked on both the Girardot Market and the Baseball Stadium "11 de Noviembre". Gaitán invented a brick unit called the "hat brick" ("ladrillo sombrero") (Figure 8), which would make the vault lighter and improve the acoustics of the room while providing a distinct interior finishing. The architect tried his invention in his own house with a barrel vault before applying it with González Zuleta to the doubly-curved shells of two theaters: Teatro de la Comedia (Bogotá, 1951-53) and Teatro Río (Girardot, 1953, demolished) (Goossens, 2013). Together, they also built the church of San Cristobal in Bogotá (1954-67), featuring a $75 \mathrm{~mm}$, reinforced-"hat-brick" shell. 


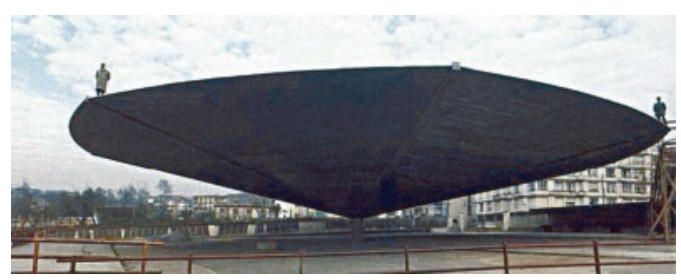

Figure 9. $40 \mathrm{~m}$-span umbrella in Pola de Siero, Spain. Ildefonso Sánchez del Río, 1971-72 (Manterola 2011).

\section{ILDEFONSO SÁNCHEZ DEL RÍO PISÓN: CURVED, HOLLOW, CONCRETE, FLOOR SLABS}

\subsection{Approach to reinforced-brick shell structures}

Ildefonso Sánchez del Río Pisón was already a master builder of concrete, thin-shell structures and a renowned engineer when he started building with the reinforced-brick technique. His work includes water tanks, bridges, markets and his famous "umbrellas" (Figure 9) (Cassinello \& Revuelta 2011).

Sánchez del Río developed 15 patents of floor systems from 1935 to 1967 . His first patents for flat floor slabs involved hollow elements made of concrete to achieve a lighter structure. In his patent of 1940 (although signed in 1938) he introduced ceramic elements in his one-directional, hollow, floor slabs (González 2011). In 1942 Sánchez del Río founded his own ceramic factory: "Río-Cerámica", with which he was able to develop patents for ceramic elements (Cassinello 2011).

One year before Dieste picked up his reinforcedbrick building activity, Sánchez del Río's patent of 1954 introduced curvature to his flat floor systems, and they became reinforced-ceramic vaults. The crosssection of this new system remained similar to the original flat floor slabs, featuring the typical prefab hollow ceramic blocks in between reinforced concrete ribs (Figure 2c). However, the addition of curvature changes its structural behaviour and turns the ceramic elements into the main structure, working in compression.

Unlike Dieste, Sánchez del Río's evolution to reinforced ceramic had its origins in hollow, concrete floor slabs that used ceramic elements to achieve a lighter structure.

As explained in the previous chapter, González Zuleta's approach was also different. However, these floor slabs with ceramic elements might have been a reference for him as well, since they were already known in Colombia in the 1940s (Galindo \& Vargas 2015, pers. comm.) (Paredes \& Garzón 1941).

\subsection{First works using reinforced brick shells}

Sánchez del Río's writings about his projects built with single-curved, reinforced-brick vaults before and after

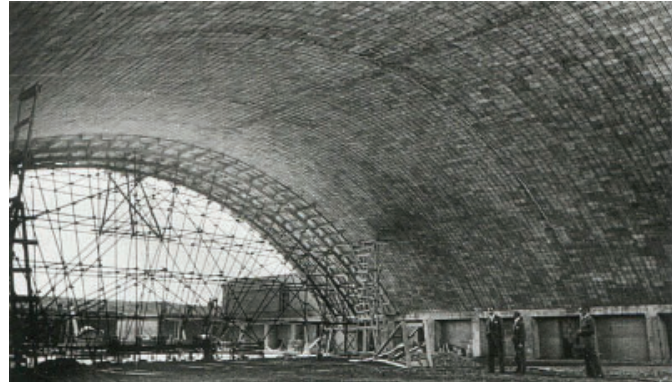

Figure 10. Warehouse for Río-Cerámica using Sánchez del Río’s technique. Project by Fernández Oliva (Revuelta 2011).

his patent in 1954 reveal vague or incomplete information about them. His articles of 1957 (Sánchez del Río 1957a, 1957b) refer to several Spanish constructions made with his technique, such as the roofs for MERSA in Lugones, the market in La Felguera, the thermal power plant in Ponferrada (Martínez 1949) and the warehouse for the factory Río-Cerámica in Madrid (Figure 10). However, no dates for the projects or their construction are given.

The maximum span achieved with these vaults was $33 \mathrm{~m}$. Built with $20 \mathrm{~cm}$-thick, ceramic pieces, they had a theoretical maximum span of $35 \mathrm{~m}$ due to buckling issues. Increasing the vault's thickness was not a desirable option, since "its lightness could be seriously affected, resulting in a disadvantage in relation to classical reinforced-concrete shells with visible stiffening ribs" (Sánchez del Río 1960). His solution was what he called the "arcos-onda" ("undulating arches" or "corrugated arches" in (Sánchez del Río 1962))

\subsection{The "undulating arches"}

The new "undulating arches" by Sánchez del Río, presented to the public for the first time in 1953, meant the addition of double curvature and prefabrication to the previously patented, vaulted system. The construction system was similar to that utilized by Nervi and his reinforced-concrete modules (used for example in the Exhibition Hall in Turin 1948-49) and the idea of introducing stiffness through waves was also not new (Cassinello 2013) (see for example the Orly hangars by Freyssinet (1923) or the Marignane Hangars by Esquillan and Perret (1950-52)). However, the combination of these characteristics in his reinforced-ceramic, prefabricated system was a novelty at the time.

The "undulating arches" were divided into "undulating voussoirs" (Figure 11), which were prefabricated on site and lifted with a crane to occupy their positions in the arch. In this case, the similarity with the procedures of Eladio Dieste lies in the use of a single formwork for an arch that is repeated along the length of the building (Revuelta 2011).

The CNIT (Centre de Nouvelles Industries et Technologies) in Paris (1958) features a similar wavy surface (Figure 12), but it could not influence Sánchez 


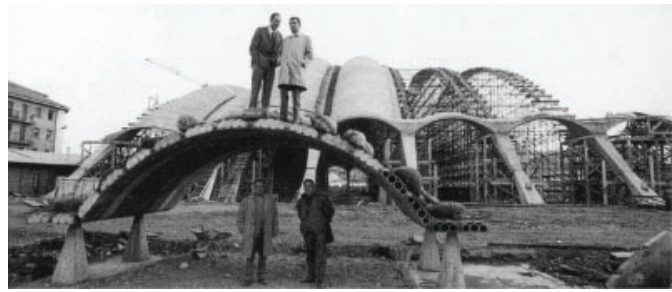

Figure 11. Load test of an "undulating voussoir", Oviedo's Sports Palace (1961-1975). Ildefonso Sánchez del Río (Cassinello 2011).

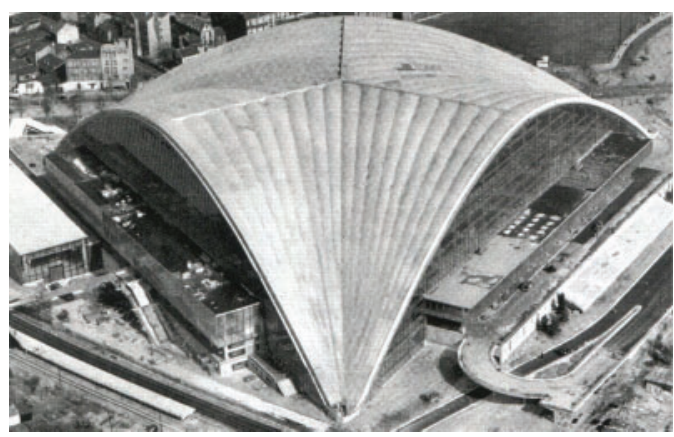

Figure 12. CNIT in Paris. Structural engineer of the shell: Nicolas Esquillan, 1958 (Cassinello 2011).

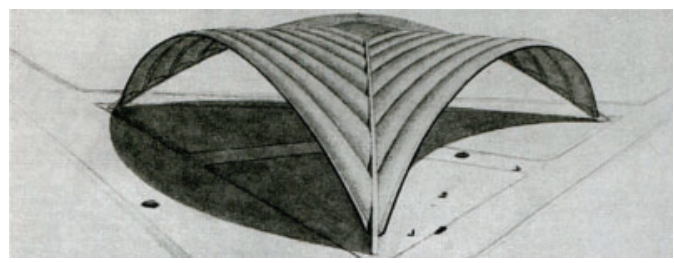

Figure 13. Design of a $200 \mathrm{~m}$-span shell using "undulating arches”. Ildefonso Sánchez del Río 1959 (Revuelta 2011).

del Río in terms of shape, since it was built later than the presentation of his "voussoirs". However, it set a challenge for him regarding the maximum span to achieve with his system. In some drawings dated 1959 (Figure 13), he proposed long-span structures similar to the CNIT. However, he never exceeded the CNIT span $(218 \mathrm{~m})$, though he achieved a span of almost $100 \mathrm{~m}$ in the Sports Palace in Oviedo (Sánchez del Río 1977) (Figure 11), $40 \mathrm{~m}$ more than the record by Eladio Dieste. To be fair, Dieste faced the problems of working with more precarious technical means and unskilled workforce (Brufau 2012).

\subsection{Calculation methods}

Despite his impressive built structures, Sánchez del Río was aware of his own limitations in the calculation of certain structures. About his "undulating arches", he stated: "given the characteristics of them, we think that

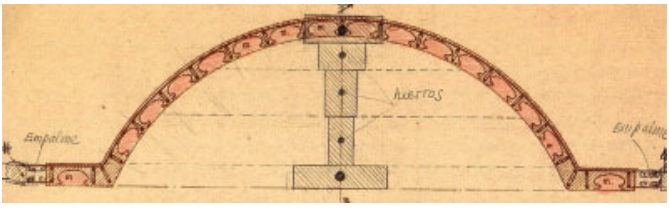

Figure 14. Sketch of the "undulating voussoir"s cross-section's mechanical equivalence to a "double-T"shaped beam. Ildefonso Sánchez del Río (Revuelta 2011).

a correct calculation is unapproachable". He had to assume a "reasonable hypothesis" of the cross-section of the arch, considering it mechanically equivalent to a "double-T"-shaped beam (Figure 14) (Sánchez del Río 1957a, 1960).

The development of the "undulating arches" was not an easy task given its structural assessment, especially considering the absence of computational tools and the level of development of structural analysis of shells at that time. On several occasions, Sánchez del Río resorted to experimental testing to develop his system (Sánchez del Río 1960). The load testing of full-scale and scaled prototypes gave some important information that he was not able to obtain graphically or numerically. Both Dieste and G. Zuleta also supported their calculations or assumptions with experimental testing at some point (Dieste 1947, Vargas \& Galindo 2015). The three engineers had to face many uncertainties on their way to innovation, but they were able to overcome them using the tools available at that time mixed with impressive ingenuity.

“...But engineers who really feel the construction, must not feel intimidated by these kind of trifles...If they do not know how to calculate it using differential equations and integrals, they should use their ingenuity (that is why they are called engineers), to get out of the woods" (Sánchez del Río, 1957a).

The Spanish engineer was of the opinion that structures should be simple and easy to calculate (Manterola, 2011). The simplicity of Graphic Statics and geometrical methods was appealing to him. For example, he used the hanging chain principle for the design of many of his undulating, thin shells (Brufau 2012) and "force polygons, funiculars and Mohr diagrams" (Sánchez del Río 1960) to calculate the structure of the market in Pola de Siero (Arregui 2011). According to Javier Manterola (Manterola 2011, quotation extracted from Luis Peñalver's $\mathrm{PhD}$ dissertation), when Ildefonso Sánchez del Río took Eduardo Torroja to see that market, Torroja asked him:

- Ildefonso, tell me how this stands.

- This, Eduardo, is a demonstration of how reinforced concrete stands without integrals.

- Well, do not exaggerate.

- How did you calculate the "Frontón Recoletos"?

- Look, Ildefonso, after three months with mathematicians, engineers and physicians and a lot of differential equations, a lot of unknowns..., at the 
end, Ildefonso, to tell you the truth, I did it more or less with a rule of thumb.

- This, Eduardo, is just the same, only that I...can draw better than you.

This conversation illustrates the natural and sincere temperament of Sánchez del Río. His writings also reflect this fact, explaining his difficulties when facing a project in direct and humble language.

Sánchez del Río published his work in different journals (Cassinello \& Revuelta 2011), some of them with international impact. His architecture could thus become known and replicated overseas. One interesting example of a direct influence from Sánchez del Río is the experimental testing of "undulating voussoirs" and other reinforced-brick, prefabricated elements made by the Ministry of Construction of Cuba. A book from 1962 (Campos 1962) shows this comprehensive research on prefabricated, reinforcedbrick elements, such as self-carrying vaults, doublycurved vaults, "sea-gull-shaped" elements, hyperbolic paraboloids, folded planar elements, space frame trusses and "undulating voussoirs". In the text, there is a direct reference to Sánchez del Río's writings, particularly to his paper published in the 9th Bulletin of IASS (Sánchez del Río 1960), which was probably available also in the rest of Latin America.

\section{CONCLUSION}

The presentation of the works and background of the engineers Eladio Dieste, Guillermo González Zuleta and Ildefonso Sánchez del Río Pisón showed three different approaches to reinforced brick architecture. Their techniques, although not completely identical, feature similar ways of building with bricks, steel reinforcement and concrete or mortar. However, a closer look at their interests, writings and previous works reveals their different original conceptions.

In the case of Dieste, the goal was to build a masonry shell. The idea came as a solution to resist the tensile stresses and bending moments that masonry vaults cannot withstand. Although pioneering, his architecture was rooted in tradition and was formulated in response to its context, within strong economic constraints. On the other hand, the approach by González Zuleta came from concrete, thin-shell architecture and the addition of ceramic elements to achieve a lighter structure. Finally, Sánchez del Río developed his technique starting from hollow, flat, concrete floor slabs and introducing curvature to create long-span roofs.

The three of them developed their new techniques almost in parallel and were facing the inherent difficulties of innovative architecture. Especially challenging was the structural analysis of the proposed shells. Each used load-testing of full-scale and/or scaled prototypes as verification of their calculations and assumptions.

Worldwide Eladio Dieste is considered to be the main figure and developer of the reinforced-brick shell technique. Indeed, his extraordinary architecture merits the most prominent place in the history of this technique. Nevertheless, the presented works by G. Zuleta and Sánchez del Río also deserve places near Dieste's in the history of reinforced-brick technique.

There is a clear gap of information about the works of all three engineers between approximately 1945 and 1960 (depending on which of the three engineers). This period is of great importance regarding the invention of the technique and its first steps, and there is still the opportunity for further, interesting research on the field.

\section{ACKNOWLEDGEMENTS}

The authors would like to thank Jorge Galindo Díaz (Universidad Nacional de Colombia), Hernando Vargas Caicedo (Universidad de los Andes) and Maarten Goossens (Universidad de los Andes) for sharing their knowledge and their work. The documents (plans, articles and pictures) sent by Jorge Galindo and Hernando Vargas, together with their accurate comments, have been essential for our research on González Zuleta's work.

The authors also wish to thank Juan Grompone for allowing the contact with Ciro Caraballo (advisor of the Uruguay's Cultural Heritage's National Commission), and Ciro Carballo for the documents, the feedback and the constructive discussions about Eladio Dieste's work.

The authors acknowledge Noelle Paulson (ETH Zurich) for her proofreading and writing assistance.

\section{REFERENCES}

Adell, J.M. 2005. Rogelio Salmona y la arquitectura con ladrillo en Colombia. Informes de la Construcción 56 (495): 73-80.

Alvárez, F. \& Roig, J. 1996. Antoni Bonet Castellana 19131989. Ministerio de Fomento \& Colegio de Arquitectos de Cataluña, Barcelona.

Anderson, S. 2004. Eladio Dieste. Innovation in Structural Art. Princeton Architectural Press, New York.

Arana, M. \& Garabelli, L. 1980. Diálogos con Dieste. In Eladio Dieste el maestro del ladrillo, Summarios 8 (45): 96-101.

Archivo General de la Nación 1947. Project: Estadio de Cartagena. Plans: 246, 937, 938, 940. District: Cartagena. Colombia.

Arregui, U. 2011. La Plaza Cubierta de Pola de Siero. In Cassinello, P. \& Revuelta, B. (ed), Ildefonso Sánchez del Río, el ingenio de un legado. Fund. Juanelo Turriano, Madrid.

Brufau, R. 2012. Ildefonso Sánchez del Río, unpublished.

Cabeza, J.M., Jiménez, J.R., Sánchez-Montañés, B., Pérez, J.I. 2009. The key-role of Eladio Dieste, Spain and the Americas in the Evolution from Brickwork to Architectural Form. Journal of Asian Architecture and Building Engineering 8 (2): 355-362.

Campos, J. C. 1962. Investigación Técnica. Ministerio de la Construcción, Cuba.

Cassinello, P. 2011. Las cubiertas de Sánchez del Río en el contexto internacional de la arquitectura moderna. In 
Cassinello, P. \& Revuelta, B. (ed), Ildefonso Sánchez del Río, el ingenio de un legado. Fund. Juanelo Turriano, Madrid.

Cassinello, P. 2013. The evolution of concrete shells; innovations by Ildefonso Sánchez del Río. Informes de la Construcción 65 (530): 147-154.

Cassinello, P. \& Revuelta, B. 2011. Ildefonso Sánchez del Río, el ingenio de un legado. Fund. Juanelo Turriano, Madrid.

Chiorino, M.A. 2003. Nascita e radici di un'arte di costruire in laterizio. In Daguerre, M. (ed.), Eladio Dieste 1917-2000. Mondadori Electa spa, Milano.

Churtichaga, J. 2010. Cerámica armada, una investigación construida. Madrid: Escuela Técnica Superior de Arquitectura de Madrid, unpublished.

Consejería de Obras Públicas y Transportes 1996. Eladio Dieste 1943-1996. Junta de Andalucía, Sevilla.

Cortés, E.C. 2014. Cáscaras y bóvedas en concreto reforzado: arquitectura religiosa de los años cincuenta en Colombia. IASS-SLTE Symposium, Brasilia.

Daguerre, M. 2003. Eladio Dieste 1917-2000. Mondadori Electa spa, Milano.

Dieste, E. 1947. Bóveda Nervada de Ladrillos "de espejo". In Tomlow, J. 2001. La bóveda tabicada y el nacimiento de la "cerámica armada". In Huerta, S. (ed.) Las bóvedas de Guastavino en América. Instituto Juan de Herrera, 2001, Madrid.

Dieste, E. 1961. Iglesia en Montevideo, templo parroquial de Atlántida. Informes de la Construcción 127: 148-160.

Dieste, E. \& Montañez, E. 1963. Estructuras cerámicas. Revista de Ingeniería, 657-60.

Dieste, E. 1987. Eladio Dieste. La Estructura Cerámica. Escala (ed.), Colombia.

García, J. \& Beltrán, M.A. 2014. La prefabricación de bóvedas de ladrillo. Una utopía latinoamericana. Rita 2: 92-99.

González, E. 2011. Las patentes de forjados de Ildefonso Sánchez de río. In Cassinello, P. \& Revuelta, B. (ed), Ildefonso Sánchez del Río, el ingenio de un legado. Fundación Juanelo Turriano, Madrid.

Goossens, M. 2013. Inventing bricks in times of concrete: attempts at innovating construction in mid-century Colombia, unpublished.

Grompone, J. 1993. Eladio Dieste, Maestro de la Ingeniería. Montevideo, unpublished.

Gutiérrez, N. 2011. La casa de Jorge Gaitán Cortés en Bogotá. Instituto Distrital de Patrimonio Cultural, Bogotá.

Manterola, J. 2011. Ildefonso Sánchez del Río Pisón, Ingeniero. In Cassinello, P. \& Revuelta, B. (ed), Ildefonso Sánchez del Río, el ingenio de un legado. Fundación Juanelo Turriano, Madrid.

Marín, A. M. \& Trallero, A. 2005. El nacimiento de la cerámica armada. Cuarto Congreso Nacional de Historia de la Construcción, Cádiz.

Martínez, A. 1949. La central termoeléctrica de Compostilla, en Ponferrada. Revista de Obras Públicas, December $1949,578-592$.
Ochsendorf, J.A. 2004. Eladio Dieste as structural artist. In Stanford Anderson (ed.), Eladio Dieste. Innovation in Structural Art (94-105).Princeton Architectural Press, NY.

Paredes, L. \& Garzón A. 1941. Encofrados en ladrillo hueco. Ingeniería y Arquitectura 3 (27): 31-32. Universidad Nacional, Bogotá.

Petrina, A. 1988. Eladio Dieste. Una estética de la ética. Summa 247: 23-32, Buenos Aires.

PROA 1952. El nuevo hipódromo de Bogotá. PROA 60: 2023, Bogotá

PROA 1955a. Edificio Volkswagen, estructuras de "ferroconcreto" ltda. PROA 93, Bogotá.

PROA 1955b. Hipódromo de Techo. PROA 90, Bogotá.

PROA 1958. Club hípico. PROA 122, Bogotá.

Revuelta, B. 2011. Breve crónica de un ingeniero bohemio. In Cassinello, P. \& Revuelta, B. (ed), Ildefonso Sánchez del Río, el ingenio de un legado. Fundación Juanelo Turriano, Madrid.

Rother, H. 1984. Arquitecto Leopoldo Rother: vida y obra. Escala (ed.), Bogotá.

Rother, L. 1967. Plaza del mercado en Girardot. Escala 20, 4.

Rodríguez, J.L. 2008. Memorias de los años 50. Conversaciones con Francisco Pizano. Dearquitectura 3: 16-29. Ed. Uniandes.

Sánchez del Río, I. 1957a. La construcción de grandes bóvedas por el sistema de "dovelas-onda". Revista de Obras Públicas 2905: 205-216.

Sánchez del Río, I. 1957b. El barrio "ondulado" FEFASA. Cemento-Hormigón 280: 335-348.

Sánchez del Río, I. 1960. Estructuras laminares cerámicas. Informes de la Construcción 119.

Sánchez del Río 1962. Corrugated reinforced ceramic shells for larger spans. World Conference on Shell Structures, San Francisco.

Sánchez del Río, I. 1977. Palacio de Deportes de Oviedo. Informes de la Construcción 29 (287): 73-85.

Tomlow, J. 2001. La bóveda tabicada y el nacimiento de la "cerámica armada". In Huerta, S. (ed.) Las bóvedas de Guastavino en América. Instituto Juan de Herrera, 2001, Madrid.

Vargas, H. 2009. El desarrollo de la edificación en concreto armado en Colombia: el caso de los pioneros Doménico Parma y Guillermo González Zuleta (1945-1985). Dearquitectura 4. Ed. Uniandes.

Vargas, H. \& Galindo, J. 2015. The construction of thin concrete shell roofs in Colombia during the first half of the 20th century: the works of Guillermo González Zuleta (1916-1995). 5th International Congress on construction History, Chicago.

Vargas, H. 2015. Mercado Súper Rayo en Bogotá. Construcción Metálica 20: 62-67.

Vélez, C., López, D., Gaviria, M., Montoya, N. 2010. Arquitectura moderna en Medellín 1947-1970. Universidad Nacional de Colombia, Medellín.7arquitecturas 2001. Estación de servicio para buses. 7arquitecturas 1: 52-53. 